\title{
Evaluation of Analgesic Activity of Paroxetine in Adult Male Albino Rats in Comparison with Diclofenac
}

\author{
C. Umamaheshwari ${ }^{1}$, M. Shanthi M. $D^{2}$, M. Malathi M.D ${ }^{3}$, R. Parameswari M.D ${ }^{4}$ \\ ${ }^{1}$ Postgraduate, Institute of Pharmacology, Madurai Medical College \\ ${ }^{2}$ Professor, Institute of Pharmacology, Madurai Medical College \\ ${ }^{3}$ Assisstant Professor, Institute of Pharmacology, Madurai Medical College \\ ${ }^{4}$ Director and Professor, Institute of Pharmacology, Madurai Medical College
}

\begin{abstract}
Background:Pain affects millions of people, leading to depression and anxiety. Paroxetine is the most potent inhibitor of serotonin re-uptake.The analgesic effect of Paroxetine has been shown both in animal models and human cases suffering from different type of chronic pain. Objectives of the Study To evaluate of analgesic activity of paroxetine in adult male albino rats in comparison with diclofenac. Methodology: The analgesic effect of graded doses of paroxetine $(2.5 \mathrm{mg} / \mathrm{kg}, 5 \mathrm{mg} / \mathrm{kg}, 10 \mathrm{mg} / \mathrm{kg}) \mathrm{was}$ evaluated using Eddy's hot plate method and tail-flick method and compared with the standard analgesic diclofenac .The values obtained are expressed as mean \pm SEM. Statistical analysis of differences between groups was carried out using one-way analysis of variance (ANOVA) . Probability (P) value of <0.05 was taken as the level of statistical significance. Results: Paroxetine showed statistically significant analgesic activity in comparison with control group and standard group $(P<0.05)$
\end{abstract}

Keywords: Analgesic effect, Paroxetine, Diclofenac, Eddys hotplate, tailflick

\section{Introduction}

Pain is an unpleasant sensory and emotional experience associated with actual or potential tissue damage [1].Analgesic medications are the first line of treatment in the pain management [2].Over the course of human history pain has been treated by psychological technique, physical method (surgical intervention, electrical stimulant, pressure, cold, heat, counter irritant, acupuncture) and by drugs [3].Severe pain due to cancer metastasis needs the use of strong analgesics like opioid drugs but addiction liability of opioid is a major drawback. In spite of vast number of drugs,search for new analgesics having better efficacy and minimal adverse effect are continuing throughout the world. Antidepressant and neuroleptic have been found to be useful in treating some type of acute and chronic pain [3].In animals antidepressants that enhance 5HT neurotransmission augment stimulation produced analgesia [4]. Paroxetine is the most potent inhibitor of serotonin re-uptake among the SSRIs [5].The analgesic effect of selective serotonin reuptake inhibitor (SSRI) has been shown both in animal models and human cases suffering from different type of chronic pain [6]

\section{Materials and Methods}

The study was carried out in the Institute of Pharmacology, Madurai medical college, Madurai after getting clearance from the Institutional Ethical Committee.(Ref no:5953/E1/5/2015 dated 22/6/2015) 30 adult albino male rats weighing $150-250 \mathrm{gm}$ were obtained from central animal house, Madurai Medical college , Madurai The animals had free access to food and water ad libitum. The animals were divided into five groups of 6 animals each. Group1 serves as control, Group 2 serves as standard and Group 3,4,5 serves as test Groups. Group 1 received Normal feed+water. Group 2 received Normal feed+water+ 10mg/kg Diclofenac ip. Group 3,4,5 received increasing doses of paroxitine $(2.5 \mathrm{mg} / \mathrm{kg}, 5 \mathrm{mg} / \mathrm{kg}, 10 \mathrm{mg} / \mathrm{kg})$ intrapertonally.

Evaluation of Analgesic effect

1) Eddy's hot plate method:

2) Tail flick method

Thermal stimulus by Eddy's hot plate method:

In this the rats will be placed on a hot plate which will be maintained at a temperature of $55 \pm 0.5^{\circ} \mathrm{C}$ throughout the test. A cut-off period of $15 \mathrm{sec}$ will considered as maximal latency to avoid injury to the paws. The time taken by the animals to lick the hind paw or jump away will be taken as the reaction time and is measured. Standard group(group II) received diclofenac sodium and the test group (Group III,IV,V) received graded doses of Paroxitine $2.5 \mathrm{mg} / \mathrm{kg}$, $5 \mathrm{mg} / \mathrm{kg}, 10 \mathrm{mg} / \mathrm{kg}$ The reaction time of the rats was recorded at $30 \mathrm{mins}, 1,2,3$ hour after drug administration. The mean of the observed values was considered for statistical analysis.

Analgesiometer by tail flick method using radiant heat from electric sources: Tail flick latencies (reaction time) of the animal will be assessed by the Analgesiometer. The strength of the current passing through the naked nichrome wire will be kept constant at 5 amps. The distance between the heat source \& tail skin will be $1.5 \mathrm{~cm}$. The site of application of the radiant heat in the tail will be maintained at $2.5 \mathrm{~cm}$, measured from the root of the tail. The time taken by the animal to withdraw (flick) its tail from the hot wire will be noted and taken as the 'reaction time. This tail flicking is considered as the end point of this test and time is measured. The cut-off time of $10 \mathrm{sec}$ is planned to avoid 


\section{International Journal of Science and Research (IJSR) \\ ISSN (Online): 2319-7064}

Index Copernicus Value (2013): 6.14 | Impact Factor (2015): 6.391

any tissue damage. Standard group(group II) received diclofenac sodium and the test group (Group III,IV,V) received graded doses of Paroxitine $2.5 \mathrm{mg} / \mathrm{kg}$, $5 \mathrm{mg} / \mathrm{kg}, 10 \mathrm{mg} / \mathrm{kg}$. The reaction time of the rats was recorded at 30mins, 1,2,3hours, after drug administration. The mean of the observed values was considered for statistical analysis.

Statistical Methods: The values obtained are expressed as mean \pm SEM. Statistical analysis of differences between groups was carried out using one-way analysis of variance (ANOVA). Probability $(\mathrm{P})$ value of $<0.05$ was taken as the level of statistical significance.

\section{Results}

Analgesic activity of paroxitine in tail flick response in rats

Table 1

\begin{tabular}{|c|c|c|c|c|}
\hline Groups & $30 \mathrm{~min}$ & $1 \mathrm{hr}$ & $2 \mathrm{hr}$ & $3 \mathrm{hr}$ \\
\hline $\begin{array}{c}\text { Group I } \\
\text { CONTROL }\end{array}$ & $9.5 \pm 0.42$ & $10.5 \pm 0.25$ & $11.2 \pm 0.48$ & $12.5 \pm 0.42$ \\
\hline Group II & $\begin{array}{c}11.9 \pm 0.40 \\
*\end{array}$ & $\begin{array}{c}12.2 \pm 0.35 \\
*\end{array}$ & $\begin{array}{c}16.2 \pm 0.87 \\
*\end{array}$ & $\begin{array}{c}20.2 \pm 0.70 \\
*\end{array}$ \\
\hline Group III & $11.6 \pm 0.49$ & $10.9 \pm 0.38$ & $11.4 \pm 0.61$ & $12.7 \pm 0.66$ \\
\hline Group IV & $10.7 \pm 0.91$ & $11.5 \pm 0.35$ & $12.2 \pm 0.79$ & $13.2 \pm 0.54$ \\
\hline Group V & $11.2 \pm 0.65$ & $11.8 \pm 0.33$ & $15.3 \pm 0.66$ & $18.8 \pm 0.54$ \\
& & & $*$ & \\
$*$
\end{tabular}

AT '3' HR - STANDARD VS TEST

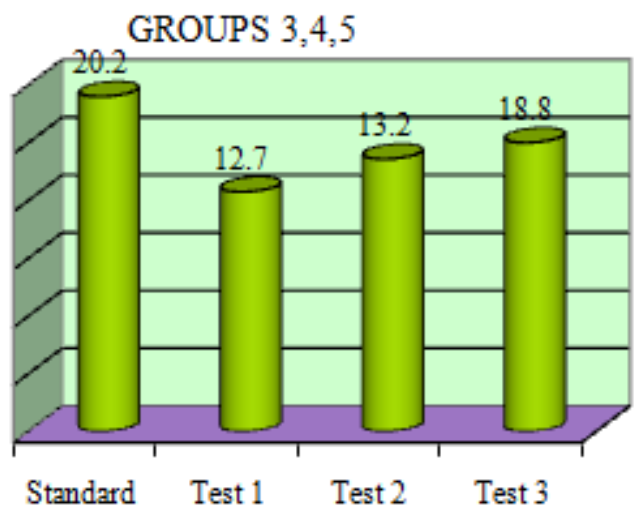

In Tail flick test, Paroxitine showed significant elevation in pain threshold in comparison to control, as represented in Table 1 and Group V showed statistically significant analgesic activity $(\mathrm{P}<0.05)$ as compared to control .. The results also demonstrated that analgesic activity produced by Paroxitine was comparable to that of standard group that received Diclofenac .

Analgesic Effect of Paroxetine in Eddys Hot Plate

Table 2

\begin{tabular}{|l|c|c|c|c|}
\hline Groups & $30 \mathrm{~min}$ & $1 \mathrm{hr}$ & $2 \mathrm{hr}$ & $3 \mathrm{hr}$ \\
\hline Group I & $3.91 \pm 0.03$ & $3.89 \pm 0.02$ & $3.85 \pm 0.04$ & $3.86 \pm 0.02$ \\
\hline Group II & $3.94 \pm 0.05$ & $7.74 \pm 0.20$ & $8.66 \pm 0.19^{*}$ & $7.70 \pm 0.32$ \\
\hline Group III & $3.89 \pm 0.04$ & $4.13 \pm 0.11$ & $4.25 \pm 0.14$ & $3.83 \pm 0.16$ \\
\hline Group IV & $3.91 \pm 0.06$ & $5.22 \pm 0.09^{*}$ & $6.30 \pm 0.16^{*}$ & $5.72 \pm 0.17^{*}$ \\
\hline Group V & $3.84 \pm 0.05$ & $6.04 \pm 0.36^{*}$ & $7.42 \pm 0.16^{*}$ & $7.25 \pm 0.08^{*}$ \\
\hline
\end{tabular}

AT '3' HR - STANDARD VS TEST

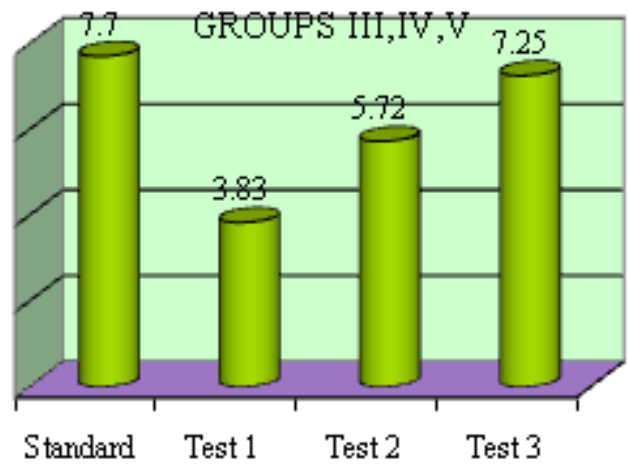

In hot-plate test, Paroxitine showed significant elevation in pain threshold in comparison to control, as represented in Table 2 and indicated statistically significant analgesic activity $(\mathrm{P}<0.05)$ as compared to control at doses 5 and 10 $\mathrm{mg} / \mathrm{kg}$.

In these pain models, treatment with paroxitine produced dose dependent analgesia and increased mean reaction time. The analgesic effect was observed within $30 \mathrm{~min}$. in diclofenac and all paroxitine groups; however, it was maintained for $120 \mathrm{~min}$. in all groups. The results also demonstrated that analgesic activity produced by Paroxitine was comparable to that of standard Diclofenac .

\section{Discussion}

In this present study analgesic effect of paroxitine selective serotonin reuptake inhibitor(SSRI) was evaluated using albino rats by tail flick and eddys hot plate method and it is found to be statistically significant.

Serotonin and norepinephrine are the neurotransmitters in diffused noxious inhibitory control probably at spinal and supraspinal level. Reuptake inhibition will enhance / prolong the effect of released biogenic amines. This might be the possible mechanism of action of paroxitine as a analgesic. Studies suggested that, the involvement of serotonergic mechanisms and serotonin receptors in analgesic effect induced by a SSRI drug, paroxetine [8]. Paroxetine provided analgesic effect for patients with refractory chronic pain.. Depression is the most common emotional disturbance in patients suffering from chronic pain [9]. The analgesic properties of psychotropic drugs were reported shortly after their introduction into psychiatric practice [2] Traditional tricyclic antidepressants have numerous undesirable side effects hence, the selective serotonin reuptake inhibitors (SSRIs), with a favorable side effect profile, are preferred [10].

This study proves that Paroxetine has antinociceptive effect and it can be used to treat pain associated with depression instead of using additional antinociceptive agent, or we can use in patients having pain likely to develop depression due to non-reduction in pain. Further studies are however necessary to explore mechanism(s) of action in depth. 


\section{References}

[1] Terry j.Baumann:pain management :joseph T.dipiro et al: Pharmacotherapy- A Pathophysiologic approach, $6^{\text {th }}$ edition, McGraw HILL, Newyork,2005, chapter 58:1089-1090.

[2] Soren H. Sindrup: Antidepressants and chronic pain : Troels Jenson et al : chronic pain, Arnold publication, London,2003, chapter 18:239-248

[3] Fields HL, Martin JB. Pain Pathophysiology and management. In:Harrisons Principles of Internal Medicine, 17th edition, Volume I, McGraw-Hill Companies, United States of America:2007, 81-86

[4] Tripathi K D: Opioid analgsics and antagonist; essentials of medical pharmacology $6^{\text {th }}$ edition, $\mathrm{J} P$ Brothers medical publishers, New Delhi, 2003,chapter 32; 424-425

[5] John Carvengh and Richard Burstal: Adjuvant therapy, Richard B Patt et al: Cancer pain, Arnold publication, London, 2003, 15:215-217

[6] Rang H.P. etal, Analgesic drugs; Pharmacology, $5^{\text {th }}$ edition, Churchill, Livingstone, London, 2003, 40; 563584

[7] Robert Arnold Turner; Analgesics; Screening methods in pharmacology, Academic press, 1965, chapter 8, page 110

[8] Duman EN, Kesim M, Kadioglu M, Yaris E, Kalyoncu NI, Erciyes N. Possible involvement of opioidergic and serotonergic mechanisms in antinociceptive effect of paroxetine in acute pain. Journal of pharmacological sciences 2004;94(2):161-5

[9] Monks. Psychotropic drugs. In: Bonica's The Management of Pain, 2nd edition, Williams and Wilkins, United States of America, 1990, 1677-1679.

[10] Masand PS, Narasimhan M, Patkar AA. Paroxetine for somatic pain associated with physical illness: a review. Primary care companion to the Journal of psychiatry. 2006;8(3):122. 